\title{
PRACTICAL ASPECTS OF AN ACTIVITY OF CONCERNED PERSONS AT REALIZATION OF COURT DECISIONS ABOUT IMPOSITION/CANCELATION OF PROPERTY ARREST IN CIVIL PROCEDURE
}

\author{
Halyna Marchenko \\ Lawyer \\ Attorney Council Poltava region \\ Director \\ Ltd. "Legal Technologies Ltd" \\ 7 Gogol str., Poltava, Ukraine, 36020 \\ moskalets.galina@yandex.ua
}

\begin{abstract}
The analysis of practical aspects of decisions of a court, executive office, public registers at securing a claim as an arrest of probable debtor's property and/or cancelation of it is carried out in the article.

This problem is an urgent and specific part of a civil procedure. It elucidates the state activity on protection of a property of society members that are under its jurisdiction.

The more effective this protection is, the more safely will social members feel themselves in the development of their economic initiatives, including in saving own resources within a state.

Just a continuous irresponsible attitude of Ukrainian state to the protection of its citizens' rights became a cause of many years stable outflow of financial resources beyond Ukraine and the absence of investments.

The information about practical complications at practical realization of court decisions is presented in the material, the evident hollows in legislation as to the practical access to justice are noted, the analysis of adjacent regulative acts and court practice in the dynamic sof existent changes is realized.

At the same time there is not studied the question of arrests cancelation at the stage of court enforcement action under condition that these arrests imposition is not a result of securing a claim but a result of executor's activity for the real execution of a court decision.

Keywords: regulatory acts, protection of property of society members, cancelation of property arrest, limitation of rights of citizens and business.
\end{abstract}

\section{Introduction}

Ukraine as an independent state, integrating the EU structures, realizes evolutional changes in its legislation for securing the main rights and freedoms of citizens, leading the guaranteeing and observance of these rights and freedoms to the high international standards.

At the same time the personal right within a society must be limited by certain norms. People in a society must observe certain rules that don't allow them to act to the detriment of other persons and ecosystem.

The general declaration of human rights, accepted and proclaimed by the resolution 217 A (III) of UNO General Assembly of 10 of December of 1948, that is a part of Ukrainian national legislation in p. 1 and 2 of art. 29, notes "every person has duties in a society, where its full and free personal development becomes possible. At realization of own rights and freedoms, each person must be limited only by items, established by a law exceptionally by guaranteeing of proper acknowledgment and respect of rights and freedoms of other people and guaranteeing of fair requirements of moral, civil order and common welfare in a democratic society" [1].

Thus, documents that provide the limitation of personal rights and as a derivative, limitation of business rights for securing justice and social order are accepted the international level.

So, the study of these rights is an important aspect of securing the proper social order, observance of general norms of justice and a rule of law. 
Based on the fact that the subject of this research is the limitation of personal rights as a result of proprietary right protection, it must be noted that art. 41 of Ukrainian Constitution of 28.06.1996 No. 254k/96-VR [2] determines the proprietary right of citizens as a basic one and art. 68 determines the duty of citizens of observe state laws.

\section{Analysis of regulatory framework and statement of problem}

A) The normative acts that are the subject of research:

- The general declaration of human rights, accepted and proclaimed by the resolution 217 A (III) of UNO General Assembly of 10 of December, 1948 [1] is the main document that the human rights protection is based on. It is a part of Ukrainian national legislation;

- The Constitution of Ukraine 28.06.1996 No. 254k/96-VR [2] determines the general principle, which observance is necessary at the protection of personal proprietary right and determines the main cases of rights limitation;

- The civil procedural Code of Ukraine [3] is a special regulatory document, on which base the claimant's right for a claim securing is guaranteed. Just shortcomings and defects of this document favor a repeated violation of concerned persons' rights;

- The Law of Ukraine "On executive proceeding” of 21.04.1999 [4];

- The Law of Ukraine "On executive proceeding" of 02.06.2016 determines the order of court decisions realization about a claim securing including [5];

- The Law of Ukraine "On securing of debtor's claims and registration of burdens" of 18.11.2003 [6] is a special regulatory act that indicates an arrest as a type of public burden, notes an order and form of registration of an arrest and release of a property from arrest.

B) The essence of problem is a limitation of citizens' and business rights, connected with securing arrangements, realized by Ukrainian courts for solving proprietary controversies.

\section{Aim and tasks of research}

The aim of this research is to elucidate in practical plane the problematics of personal proprietary interests limitation that is realized within the form of a claim securing - arrest of a property and/or funds of a debtor.

The tasks of research is a revelation of possibilities of legal relations subjects' misuse of their property protection right, cases of not grounded delay of the state at citizens' and economic subjects' rights protection and also the offers as to legislation improvement.

\section{Materials and methods of research}

The material of research is the Ukrainian laws that regulate procedural norms as to the imposition of burdens such as an arrest. The main method of research is the analysis of Ukrainian laws and their consideration in the practical plane.

\section{Results of research}

What is an arrest of a debtor's property? All conventionally understand that it is certain limitations of rights but neither the Economic procedural Code of Ukraine [7], no Civil procedural Code of Ukraine [3], no the Law of Ukraine "On executive securing" [4, 5], as special regulatory acts, don't presents the distinct definition of the correspondent term.

According to the common rule, a property arrest in the sense of a claim securing is such limitation of a defendant's rights in a civil and/or economic case in which result the last is limited in realization of own right to own resources disposed by a defendant or third persons.

Such rights limitation is usually in the limitation of right to disposal, and in any case also to possession of property and/or funds, but it doesn't deprive of the property right.

Securing a claim such as an arrest is in insertion of the information about limitations such as an arrest into correspondent public registers and/or insertion of the information about an arrest of a debtor's funds on accounts in bank institutions, determined by a court [8]. 


\section{1. Arrest as a type of a claim securing}

In a civil procedure the question of a claim securing is elucidated in chapter 3 of the Civil procedural Code of Ukraine (in further CPC) [3]: art. 151-155.

Despite the fact that chapter 3 of CPC is named "Proceeding in case before a court hearing", p. 3 art. 150 of this chapter indicates that "securing of a claim is allowed at any stage of civil case hearing, if non-act may complicate the realization of court decision or make it impossible".

So, the norm that must usually regulate the proceeding in a civil case before the beginning of hearing of its essence, at the same time establishes the order of arrangements for a claim securing if the need for them appears at other stages of a court hearing.

Just a property arrest as a type of a claim securing is noted in art. 152 of CPC: "a claim is secured by an arrest imposition on a property, owned by a defendant, disposed by him/her or other persons".

P. 2 of art. 152 of CPC notes that a court may use several types of a claim securing. At the same time just the formulation of norm about an arrest possibility includes a contradiction. Thus, a legislator notes that an arrest may be imposed on a debtor's property or funds.

Thus, a court is lawlessly limited in its authorities as to a claimant's right protection that is a violation of the general norms of art. 29 of the Declaration, because at the necessity of arrest of most number of different assets, a court may chose only one type of securing.

Example: the defendant in the case owes $1 \mathrm{mln}$ hryvnyas to the claimant; he has an auto with the cost 500 thousand hryvnyas and deposit for 500 thousand hryvnyas. It would be logic to use the arrangements of claim securing within the claim cost $-1 \mathrm{mln}$ hryvnyas, imposing arrest on both auto and deposit, but it is impossible, because a legislator used the word "or".

A claimant may use a procedural trick and give an application for a claim securing twice in one procedure, but neither an expert judge, nor competent defendant don't allow a claimant to use such possibility.

Proportionality is an important component of an arrest essence. The volume of securing must correspond to the volume of a declared claim. That is, according to procedural norms, it is illegal to impose arrest on a property or funds in more volume than a claim cost.

In this case the following procedural collisions appear. For example, the cost of declared claim is 100 thousand hryvnyas, the defendant has a real estate with oriented cost 500 thousand hryvnyas and no other property. If arrangements of a clam securing are not used, the unprincipled defendant can sale this estate before receiving a court decision, and its real execution may become impossible. At the same time if impose arrest, the cost of securing will essentially exceed the claim cost that formally causes a violation of personal proprietary rights.

In such cases Ukrainian courts usually observe the CPC norms and take a defendant's side that is not always expedient.

If arrest is imposed on a property of more cost and a defendant is not limited in using it, the rights violation is minimal, and defendant's eventual losses don't exceed a claimant's ones comparing with a situation, when an application about a claim satisfying is refused, and an existent property is alienated.

Sometimes participants of legal relations present claims with the aim not to win or lose a controversy but to limit another side of certain conflict in recourses use. In such cases, having received a decision about a claim securing, a claimant delays a case hearing by him/her own. Thus, a present claim securing is used not as a defense method but as a way of pressure for attaining an aim, not directly related to an existent juridical proceeding.

At the same time the use of legal norms even for unprincipled aims is also the personal right that may be used in any way, provided by the law.

To avoid such influence on socially unprotected categories of persons and also organs that may influence the bases of social order and state financial system, a legislator has limited the right of an arrest of funds of social purpose (p. 4 of art. 152 of CPC), funds and property that were earlier arrested in a criminal proceeding (p. 8 of art. 152 of CPC), and also on funds that are on correspondent bank accounts (LU "On banks and bank activity" [9].

It is also prohibited to impose arrest on things that are spoiled fast. 


\section{2. The order of arrest right realization in civil procedure}

Presentation of an application on claim securing and its consideration by a court

As it has been noted above, an application on a claim securing may be presented at any stage of civil procedure, including at addressing to a court with a claim and in cases, defined in p. 4 of art. 152 of CPC, even before presenting a claim.

Such application is considered without informing a defendant and is paid by a court fee, separately from a claim. The amount of fee is determined by the Law of Ukraine "On court fee" [10] and is for juridical persons $50 \%$ of minimum subsistence level, for natural persons and natural persons-entrepreneurs $-20 \%$.

CPD determined different terms of a court trial of an application on a claim securing:

A) at presentation of an application on securing together with a claim, a court must adjudge it during 2 days;

B) at addressing with such application at other stages of procedure (after closing a proceeding) - at the very day of its admission to a court);

C) an application on a claim securing, presented earlier than a claim to a court, is considered during 2 days.

In practice courts in most cases violate these procedural terms and are not responsible for that.

Based on a system character of breaking the aforesaid terms of considering applications on a property arrest, the author of this research doesn't find any practical use in them.

An application about securing a claim must be presented in the form according to the requirements of art. 151 of CPC.

So, alongside with a court fee, a claimant must ground the necessity of a defendant's property or funds arrest and form an application for securing a claim properly.

So, a legislator makes a decision of securing a claim dependent not only on objective case circumstances but on formal ones too.

According to p. 8 of art. 153 of CPC, an application about securing a claim, presented without observance of formal signs, must be returned to a claimant. Such rules correspond to the principle of sides competition, where a claimant must prove the relevancy of own requirements.

Under such conditions the role of a representative in a court procedure grows, because just the quality of his/her work mainly determines a result of consideration of an application of securing a claim.

As a result of consideration of an application of securing a claim, a court may satisfy it partially or in full. Courts often refuse of securing a claim that formally contradicts to the norms of p. 6 of art. 153 of CPC, where is noted: "depending on case circumstances, a court may secure a claim in full or partially". A judgment of full refusal in securing a civil claim is not provided by $\mathrm{CPC}$, but the court practice goes another way.

\section{3. Cancelation/appeal of a judgment on securing a claim}

A claim securing such as an arrest or any other form may be canceled as following:

1. Both defendant and claimant have a right to present an application on cancelation of arrangements of securing a claim.

Such application is presented by a defendant during 5 days from the moment of getting a decision about securing a claim and is considered by a court during 2 days after presentation (p. 4 of art. 154 of CPC ).

The claimant's right for presenting an application on cancelation of arrangements of securing a claim is not directly provided, but p. 3 of art. 154 of CPC notes that arrangements of securing a claim may be cancelled by a court that stated a decision about securing.

Based on the fact that a court doesn't have any procedural possibility to consider questions on arrest cancelation, p. 3 of art. 154 of CPC may be used by an application of any concerned participants of a procedure.

In the practical plane p. 3 of art. 154 of CPC is used mainly in such cases, when at the stage of final realization of a court decision, a claimant of a civil case, who gain a status of creditor in executive proceeding at the stage of realization of a court decision, cannot realize a debtor's prop- 
erty because of arrangements of securing a claim, used by a court at the stage of hearing a case in order of a civil procedure.

There are also repeated cases, when a defendant addresses with an application on cancelation of arrangements of securing a claim at a voluntary execution of a court decision.

An application on cancelation of arrangements on securing a claim is not paid by a court fee.

A decision about cancelation of arrangements of securing a claim is subjected to appeal as it is determined by art. 292-293 of CPC of Ukraine.

An acceptance of application against a decision about cancelation of arrangements of securing a claim stops its execution.

\section{Appeals order}

The other way to release a property from arrest is an appeal.

A decision about securing a claim according to the art. 292-293 of CPC may be appealed by any participant of a procedure or a person, who doesn't participate in a case but a claim securing violates his/her rights.

An appeal is paid by a court fee in general order.

Based on procedural possibilities of a court of primary jurisdiction, an appeal of decision about securing a claim is an extreme and not obligatory measure. At the same time it is a way of influencing a court of primary jurisdiction for avoiding illegal decisions.

An appeal about securing a claim doesn’t stop its execution.

\section{4. Executive proceeding}

The most interesting stage of realization of an arrangement of securing a claim such as an arrest is an executive proceeding.

That is, if a claimant has passed all circles of procedural hell and at least received a court judgment about securing a claim, accordingly to art. 154 of CPC such judgment must be executed in the order, determined for court decisions execution.

Execution of court decisions in Ukraine is regulated by the Law of Ukraine "On executive proceeding".

In this sense a judgment about securing a claim, received by a claimant, must correspond to the formal signs of executive document, as it is noted in art. 4 of the Law of Ukraine "On executive proceeding".

That is if a court has formed a judgment about securing a claim with non-observance of counted legal norms, an executive proceeding cannot be started, and an executive document is returned to an applicant without execution.

In this case an applicant in civil case has several interesting legal possibilities to protect own right by the following ways: decision;

A) to appeal against executor's actions;

B) to address to a court with an application with a corrected erratum in the received court

C) to address to a court with an application about an explication of court decision.

An appeal of executor's actions is a separate juridical procedure, but a complaint is considered by a court that is solving a case in essence.

According to a result of hearing a complaint on public executor's actions, a court makes a judgment that may be also appealed.

A court judgment about an erratum or explication elimination may be appealed too.

At the same time there is a contradiction in the interpretation of legal norms as to making a judgment about explanation of a judgment of securing a claim. Thus, according to art. 208 of CPC [3] court decisions exist in following procedural forms: a) court decision; b) court judgment; c) court resolution.

Art. 221 of CPC allows to explain only decisions of a court and not court decisions.

At the same time art. 31 of LU "On executive proceeding” [5] gives a right to both a public executor and sides of executive proceeding to address to a court with an application on explication of any executive documents including court judgments about securing a claim. 
So, there is a discord, according to which CPC directions that don't provide explications of court judgments as a court decision and not a decision of court are changed by another legislative act.

And finally a happy claimant, having received all necessary documents presents to an executor an application about an enforcement of a court decision that secures a claim.

At that he/she must:

A) to present an application about an enforcement of a court decision;

B) to pay an advance installment for realization of executive actions in amount of $1 \mathrm{~min}$ imal wages.

So, the total sum of a claimant - natural person's direct costs since the moment of addressing to a court with an application about securing a claim till the moment of beginning of its execution is $3520 \mathrm{hrn}$. for 01.04.2017.

A cost of juridical services is not included in this sum.

If there are no technical infractions, a procedure usually takes near 1 month from the moment of presenting an application about securing a claim till the one of factual inclusion of an arrest of a property or funds in registers.

This period includes the following situations, not provided by the procedural law: illness/dismissal of an executor, who earlier received an executive document for execution; malfunction in the system of e-registers and so on.

But a legislator noted that a notary also may register an arrest, imposed according to a court decision that is why if you want to be active, it is desired to use notary's services in such cases.

\section{5. Executor's actions on inclusion of information about a burden in arrest form in public registers}

A) As to movables

This process is regulated by the Law of Ukraine "On securing of debtor's claims and registration of burdens" (p. 2,5 of art. 37 ). This law notes the additional requirement as to designing a document, on which base the information about public burdens is included in a register (art. 43) and the order of including such information (art. 44).

The information about an arrest is inserted by a public executor on a base of an authorized person's application.

B) As to real estate

The order of inclusion of the information about an arrest as a type of securing a claim in a register of real estate is analogous to the one, determined by the Law about burdens registration but has several features, the main of which is a fact that the information about a real estate burden is included for the 5 years term, and information about an arrest - exceptionally till the moment of its cancelation.

The inclusion of information about stopping an arrest burden is realized analogously to the inclusion of information about its imposition. That is, canceling document, authorized person's application and in several cases costs payment are necessary.

The question about forms of applications, presented to a public registrar is a problem. During the last 5 years these forms changed near 5 times that rather often led to shortcomings at designing documents, so it is inexpedient to fill up any forms for a public registrant beforehand and independently, it is better to do it directly at a registrar's reception.

We must repeat that if a judgment about a debtor's property arrest, presented to a public registrar, doesn't correspond by form to the requirements of aforesaid laws (except LU "On executive proceeding"), a state registrar has an absolute right to refuse the insertion of information about imposition/cancelation on an arrest. In such case it is possible to appeal against public registrar's actions or address to a court for elimination of a defect in a document about imposition/cancelation of an arrest. Each court decision as to the specification of previous one or recognition of illegality of public registrar's actions may be appealed.

In its turn the untimely inclusion of information about an arrest to state registers may result in property alienation. If a debtor knew about an arrest, alienation of arrested property, which information was untimely included to a register, may be appealed in a court. In other cases a property that can in future satisfy creditor's requirements will be most likely lost for this creditor. 


\section{Discussion of research results}

During last years Ukraine achieved an essential progress in observing procedural rights of procedure participants.

In this sense the important aspect is an e-document circulation that favors a court impartiality and procedural economy.

Under usual conditions an agreement on property alienation (including documents preparation) takes $2-3$ business days.

Thus, securing a claim that may be in fact realized only in several weeks may be effective only in exclusive cases.

\section{Conclusions}

The following was established as a result of research.

The system of securing a claim in Ukrainian civil procedure is excessively loaded with a documents circulation. There are in fact no distinct rules that may be used by an honest claimant to defend own right before a solution of a controversy in a court.

Such load is created by the system of paper registration and uncertainty of rules of imposition/cancelation of arrests.

The legislative mistakes: I find it necessary to introduce changes in the norms of art. 152 of CPC of Ukraine. Such changes may allow a court to arrest synchronously funds and property of a debtor, securing a claim.

For effective execution of decisions about arrests I find it necessary to introduce changes in the Law of Ukraine "On executive proceeding" and Civil procedural Code of Ukraine that would oblige a claimant to note in an application about securing a claim an enforcement organ that he/she wants to address to in the case of satisfying his/her application. At the same time it is necessary to oblige courts to note an organ of arrest enforcement in a judgment on securing a claim. In further a court must direct a requirement about arrest to an executor independently, without a claimant's participation by e-message.

Such improvements would provide a real effectiveness at realizing arrangements of securing a claim.

A court and executive fee payment must take place synchronously, at presenting an application about securing a claim. The distribution of costs between a court budgetary account and executor's one must be realized by the State treasury.

\section{References}

[1] Zahal'na deklaratsiya prav lyudyny pryynyata i proholoshena rezolyutsiyeyu 217 A (III) Heneral'noyi Asambleyi OON vid 10 hrudnya 1948 roku (2008). Holos Ukrayiny, 236.

[2] Konstytutsiya Ukrayiny vid 28.06.1996 No 254k/96-VR (1996). Vidomosti Verkhovnoyi Rady Ukrayiny, 30, 141.

[3] Tsyvil'nyy protsesual'nyy kodeks Ukrayiny vid 18.03.2004 No 1618-IV (2004). Ofitsiynyy visnyk Ukrayiny, 16, 1088, 28609/2004.

[4] Zakon Ukrayiny «Pro vykonavche provadzhennya» vid 21.04.1999 No 606-XIV (1999). Available at: http://zakon.rada.gov.ua/go/606-14

[5] Zakon Ukrayiny «Pro vykonavche provadzhennya» vid 02.06.2016 No 1404-VIII (2016). Available at: http://zakon2.rada.gov.ua/laws/show/1404-19

[6] Zakon Ukrayiny «Pro banki i bankivs'ku diyal'nist'» 07.12.2000 No 2121-III (2001). Available at: http://zakon3.rada.gov.ua/laws/show/2121-14

[7] Zakon Ukrayiny «Pro zabezpechennya vymoh kredytoriv ta reyestratsiyu obtyazhen'» vid 18.11.2003 No 1255-IV (2004). Available at: http://zakon3.rada.gov.ua/laws/show/1255-15

[8] Hospodars’kyy protsesual'nyy kodeks Ukrayiny vid 06.11.1991 № 1798-XII (1992). Vidomosti Verkhovnoyi Rady Ukrayiny, 6, 56.

[9] Zakon Ukrayiny «Pro derzhavnu reyestratsiyu rechovykh prav na nerukhome mayno ta yikh obtyazhen'» vid 01.07.2004 No 1952-IV (2004). Available at: http://zakon.rada.gov.ua/go/1952-15

[10] Zakon Ukrayiny «Pro sudovyy zbir» vid 01.01.2017 No 3674-17 (2017). Available at: http:// zakon.rada.gov.ua/laws/show/3674-17 